\title{
On Craterocolla and Ditangium (Sebacinales, Basidiomycota)
}

\author{
Vera Malysheva $^{1} \cdot$ Viacheslav Spirin $^{2,3}$ (D) $\cdot$ Otto Miettinen $^{2} \cdot$ Jiří Kout $^{4} \cdot$ Anton Savchenko $^{5} \cdot$ Karl-Henrik Larsson $^{3}$
}

Received: 2 October 2018 / Revised: 2 March 2019 / Accepted: 8 March 2019

(C) The Author(s) 2019

\begin{abstract}
In the present paper, we select a neotype for Tremella cerasi and prove that it is conspecific with Ditangium insigne (the genus type of Ditangium). We argue that Ditangium should be restored as a correct genus for $T$. cerasi, while the currently used generic name Craterocolla is to be treated as its younger synonym. Morphological, ecological and genetic variability of Ditangium cerasi is discussed, and two other Ditangium species are described-D. altaicum, sp. nov. and D. incarnatum, comb. nov. In addition, Exidia fulva is combined in Globulisebacina.
\end{abstract}

Keywords Dimorphic fungi $\cdot$ Heterobasidiomycetes $\cdot$ New taxa $\cdot$ Phylogeny $\cdot$ Taxonomy

\section{Introduction}

Craterocolla cerasi (Schumach.) Bref. is a jelly fungus well known to mycologists due to a peculiar crater-like anamorphic stage (Hansen and Knudsen 1997; Oberwinkler et al. 2014). According to recent DNA-based studies, Craterocolla has been placed to the Sebacinales (Agaricomycetes, Basidiomycota) (Weiss et al. 2004; Oberwinkler et al. 2014). In these studies, the genus was considered monotypic i.e., limited to the type species, Tremella cerasi Schumach., but no attempts to clarify its identity, as well as the genus concept, were performed.

This article is part of the "Topic collection on Basidiomycote Mycology in honour of Franz Oberwinkler who passed away in March 2018".

Section Editor: Meike Piepenbring

Viacheslav Spirin

viacheslav.spirin@helsinki.fi

1 Komarov Botanical Institute, Russian Academy of Sciences, Prof. Popova str. 2, St. Petersburg, Russia 197376

2 Finnish Museum of Natural History, University of Helsinki, PO Box 7, 00014 Helsinki, Finland

3 Natural History Museum, University of Oslo, P.O. Box 1172, Blindern, 0318 Oslo, Norway

4 Department of Biology, Geosciences and Environmental Education, Faculty of Education, University of West Bohemia, Klatovská 51, CZ-306 19 Plzeň, Czech Republic

5 Institute of Ecology and Earth Sciences, University of Tartu, Lai 40, EE-51005 Tartu, Estonia
No type material for $T$. cerasi has been located and its protologue (Schumacher 1803) is obscure and thus opened to controversial interpretations (Donk 1966). In particular, Fries (1822) did not accept this species and simply treated it among synonyms of Tremella sarcoides (Jacq.) Fr. (now Ascocoryne sarcoides (Jacq.) J.W. Groves \& D.E. Wilson, Ascomycota). The current understanding of T. cerasi originates from Tulasne and Tulasne (1873). The latter authors associated Schumacher's species name with a jelly fungus inhabiting cherry trees in France and having longitudinally septate, four-celled basidia and cylindrical, curved basidiospores, as well as a characteristic anamorph. When Brefeld (1888) introduced the genus Craterocolla, he relied on the Tulasne's understanding of T. cerasi, and this interpretation has been accepted by most subsequent authors (Saccardo 1888; Neuhoff 1935, 1936; Pilát 1957 etc.). Two earlier generic names, Ditangium P. Karst. (Karsten 1867) and Poroidea Göttinger (in Sauter 1880), were treated as heterotypic synonyms of Craterocolla (Donk 1966; Wojewoda 1981) but disregarded in favour of the latter.

In the present study, we designate a neotype for Tremella cerasi and revise available specimens of Craterocolla cerasi from boreal-temperate Northern Hemisphere. The identity of Ditangium insigne P. Karst. and Exidia testacea Raitv. is clarified based on morphology and DNA studies of types. In addition, a new combination in Globulisebacina is proposed. This paper is our homage to Prof. Franz Oberwinkler, one of the most distinguished researchers of jelly fungi, in particular the Sebacinales. 


\section{Material and methods}

Type specimens and other collections from herbaria $\mathrm{H}, \mathrm{LE}, \mathrm{O}$, UPS, TRH, S, TAAM, CWU, as well as from the Mycological Herbarium of the Department of Biology, University of West Bohemia, Czech Republic (informally abbreaviated KBI), were studied. Herbarium acronyms are given according to Thiers (2016). Microscopic routine follows Miettinen et al. (2018). All observations and measurements were made from microscopic slides prepared in Cotton Blue, using phase contrast and oil immersion lens (Leitz Diaplan microscope, $\times 1250$ amplification). At least $20-30$ basidiospores and 10-20 conidia were measured for each studied specimen. The following abbreviations are used in microscopic descriptions: $L$-mean cell length, $W$-mean cell width, $Q^{\prime}$-length/width ratio, $Q$-mean length/width ratio, $n-$ number of measurements per specimens measured.

DNA extraction and sequencing For DNA extraction, small fragments of dried basidiocarps were used. In total, 14 specimens were selected for molecular sampling (Table 1). DNA was extracted using the NucleoSpin Plant II Kit (MachereyNagel GmbH \& Co. KG) according to the manufacturer's instructions. The following primers were used for both amplification and sequencing: ITS1F-ITS4 (White et al. 1990; Gardes and Bruns 1993) for ITS region; primers EF1-983F and EF1-1567R for approximately 500 bp of tefl (Rehner and Buckley 2005). PCR products were purified applying the GeneJET Gel Extraction Kit (Thermo Scientific, Thermo Fisher Scientific Inc., MA, USA). Sequencing was performed with an ABI model 3130 Genetic Analyzer (Applied Biosystems, CA, USA). Raw data were edited and assembled in MEGA 6 (Tamura et al. 2013).

Phylogenetic analyses For this study, 19 ITS and 15 tefl sequences were generated. Additionally, four sequences (three nrITS and one tefl) including the outgroups were retrieved from GenBank (www.ncbi.nlm.nih.gov/genbank/). GenBank matches as well as preliminary multiple alignments prepared by us showed that tef1 sequences of Ditanigum spp. obtained for this study contain two introns. These introns were

Table 1 Data for nrITS and tef1 sequences used in the phylogenetic analyses

\begin{tabular}{|c|c|c|c|c|c|c|}
\hline Species & $\begin{array}{l}\text { Collector/herbarium } \\
\text { number }\end{array}$ & $\begin{array}{l}\text { Origin } \\
\text { (ISO code) }\end{array}$ & Host & nrITS GenBank \# & tef1 GenBank \# & Source \\
\hline Ditangium altaicum & LE 231836 & RU & Alnus sp. & MH836338 & MH910034 & This study \\
\hline D. cerasi & 2.I.2010 Kout (KBI, H) X4196 & $\mathrm{CZ}$ & Cerasus sp. & MH836373 & - & This study \\
\hline D. cerasi & $\begin{array}{l}\text { 30.IX.2002 Kout } \\
\text { (KBI, H) X4197 }\end{array}$ & $\mathrm{CZ}$ & Cerasus sp. & MH836374 & MH910035 & This study \\
\hline D. cerasi & Karsten $3508(\mathrm{H})$ & FI & Picea abies & MH836341 & - & This study \\
\hline D. cerasi & Hyvärinen (H ex O) & FI & Betula sp. & MH836326 & - & This study \\
\hline D. cerasi & Junninen $2314(\mathrm{H})$ & FI & Picea abies & MH836327 & MH910021 & This study \\
\hline D. cerasi & VS $11073(\mathrm{O})$ & NO & Alnus incana & MH836329 & - & This study \\
\hline D. cerasi & LE 254072 & RU & Picea orientalis & MH836335 & MH910028 & This study \\
\hline D. cerasi & LE 254074 & RU & Picea orientalis & MH836340 & MH910030 & This study \\
\hline D. cerasi & & & & & & This study \\
\hline D. cerasi & LE 254073 & $\mathrm{RU}$ & Abies nordmanniana & MH836339 & MH910029 & This study \\
\hline D. cerasi & LE 312775 & RU & Pinus sibirica & MH836334 & MH910027 & This study \\
\hline D. cerasi & TAAM 9173 & RU & Abies sibirica & MH836342 & & This study \\
\hline D. cerasi & VS 3846 (H) & RU & Picea ajanensis & MH836330 & MH910024 & This study \\
\hline D. cerasi & VS $3889(\mathrm{H})$ & RU & Pinus pumila & MH836332 & MH910026 & This study \\
\hline D. cerasi & VS 4677 (H) & RU & Picea abies & MH836328 & MH910022 & This study \\
\hline D. cerasi & VS $10466(\mathrm{H})$ & RU & Betula pubescens & MH836331 & MH910025 & This study \\
\hline D. cerasi & LE 294521 & RU & Pinus koraiensis & MH836333 & MH910023 & This study \\
\hline Craterocolla cerasi & AFTOL-ID 1677 & - & - & DQ520103 & - & Unpublished \\
\hline C. cerasi & strain TUB 020202 & $\mathrm{DE}$ & $\begin{array}{c}\text { fruit body on stems } \\
\text { of Prunus avium }\end{array}$ & KF061264 & - & $\begin{array}{r}\text { Oberwinkler } \\
\text { et al. } 2014\end{array}$ \\
\hline D. incarnatum & Haikonen 28,811 (H) & FI & Populus tremula & - & MH910031 & This study \\
\hline D. incarnatum & LE 206311 & $\mathrm{RU}$ & Populus tremula & MH836336 & MH910033 & This study \\
\hline D. incarnatum & LE 303419 & $\mathrm{RU}$ & Populus tremula & MH836337 & MH910032 & This study \\
\hline $\begin{array}{l}\text { Serendipita } \\
\text { vermifera }\end{array}$ & strain MAFF305835 & $\mathrm{AU}$ & $\begin{array}{l}\text { Orchid mycorrhiza of } \\
\text { Caladenia catenata }\end{array}$ & DQ983814 & JN211116 & $\begin{array}{l}\text { Deshmukh } \\
\text { et al. } 2006\end{array}$ \\
\hline
\end{tabular}


phylogenetically informative, and therefore they were not removed from the phylogenetic analyses.

Sequences were aligned with the MAFFT version 7 web tool (http://mafft.cbrc.jp/alignment/server/) using the Q-INS-i option for nrITS. Phylogenetic reconstructions for three data sets (nrITS, tef1, nrITS+tefl) were performed with maximum likelihood (ML) and Bayesian (BA) analyses. Before the analyses, the best-fit substitution models for the alignment were estimated for each dataset based on Akaike Information Criterion (AIC) using FindModel web server (http://www. hiv.lanl.gov/content/sequence/findmodel/findmodel.html). Selected models were as follows: 'GTR plus Gamma' for nrITS dataset; 'GTR' for nrITS+tefl dataset; 'TrN: TamuraNei plus Gamma' for tefl dataset.

ML analyses were run in the PhyML server, v. 3.0 (http:// www.atgc-montpellier.fr/phyml/), with 1000 rapid bootstrap replicates. BA was performed with MrBayes 3.2.5 software (Ronquist et al. 2012), under selected model for each data set, for two independent runs, each with 5 million generations with sampling every 100 generations and four chains. Tracer v. 1.6.0 (Rambaut et al. 2014) was used to evaluate the quality of a sample from the posterior and the continuous parameters, using effective sample size (ESS). We accepted the result where the ESS (effective sample size) was above 200 and the PSRF (potential scale reduction factor) was close to 1 . The clades with posterior probability $(\mathrm{PP})$ value $>0.95$ were considered to be significantly supported.

Newly generated sequences have been submitted to GenBank (Table 1) and alignments to TreeBase (S23714, S23715, S23721).

Specimens examined (sequenced specimens are marked by asterisk)

Ditangium altaicum. Russia. Altai Republic: Ulagan Dist., Altai Nat. Res., Alnus sp., 18.VIII.2008 Malysheva (LE 231836*, holotype).

D. cerasi. Czech Republic. Central Bohemia: Roztoky, Řivnáč hill, Prunus cerasus, 2.I.2010 Kout* (KBI, H 7008918). South Bohemia: Tábor, Chýnov, P. cerasus, 30.IX.2002 Kout (H 7008919*-neotype of Tremella cerasi, KBI-isoneotype). Finland. Etelä-Häme: Tammela, Mustiala, Picea abies, 10.X.1866 Karsten 3508* (H, lectotype of Ditangium insigne). Perä-Pohjanmaa: Tervola, Hirvikumpu, Betula sp., 20.X.2005 Hyvärinen* (H). Kittilän Lappi: Kolari, Kesänkijärvi, P. abies, 6.V.2016 Junninen 2314* (H). France. Aveyron: St. Sernin, P. cerasus, III.1905 Galzin 810 (herb. Bourdot 4566) (UPS). Germany. Bayern: GarmischPartenkirchen, Oberammergau, P. abies, VIII.1894 Schnabl (as Poroidea pithyophila, H ex Fungi Bavarici \#936). Norway. VestAgder: Mandal, Uføra, Quercus robur, 2.XI.2017 Spirin 11773 (O). Oppland: Sel, Sagåa Nat. Res., Alnus incana, 13.IX.2016 Spirin 11073*(O). Nor-Trøndelag: Steinkjer, Byahalla Nat. Res., A. incana, 11.V.2014 Holien 22/14 (TRH F15861). Russia. Karachaevo-Cherkessia: Karachaevsk Dist, Teberda
Nat. Res., Picea orientalis, 8.VIII.2009 Malysheva (LE 254072*, LE 254074*), Abies nordmanniana, 12.VIII.2009 Malysheva (LE 254073*). Komi Rep.: Troitsko-Pechersky Dist., Pechoro-Ilych Nat. Res., P. abies, 13-15.IX.1992 Hermansson \& Lundqvist (UPS F-013743, F-013748), Pinus sylvestris, 19.IX.1992 Hermansson \& Lundqvist (UPS F-141037). Krasnoyarsk Reg.: Ermakovskoe Dist., SayanoShushensky Nat. Res., Pinus sibirica, 27.VIII.2015 Malysheva (LE 312775*); Mansky Dist., Badzhei, Abies sibirica, 6.IX.1958 Parmasto (TAAM 9173*, holotype of Exidia testacea). Khabarovsk Reg.: Solnechny Dist., Igdomi, Picea ajanensis, 6.VIII.2011 Spirin 3846* (H), Pinus pumila, 6.VIII.2011 Spirin 3889* (H). Leningrad Reg.: Boksitogorsk Dist., Kolp', P. abies, 26.IX.2011 Spirin 4677* (H), Vozhani, Betula pubescens, 30.VII.2016 Spirin 10466* $(\mathrm{H})$. Primorie. Ternei Dist.: Sikhote-Alin Nat. Res., Pinus koraiensis, 24.VIII.2012 Malysheva (LE 294521*). Slovakia. Banská Bystrica: Banská Štiavnica, Prenčov, Malus sp., 3.XI.1896 Kmet (UPS). Ukraine. Ivano-Frankivsk Reg.: Nadrivna Dist., Carpathian Nat. Park, P. abies, VI.2011 Akulov (CWU 7018).

D. incarnatum. Finland. Etelä-Häme: Iitti, Säyhtee, Populus tremula, 25.IV.2012 Haikonen 28811* (H); Tammela, Mustiala, Salix pentandra, 1.IX.1886 Karsten 1324 (H 6049583, lectotype of Dacrymyces incarnatus). Norway. Akershus: Nannestad, Sundby, P. tremula, 17.IX.1964 Eckblad (O F160849). Russia. Leningrad Reg.: Priozersk Dist., Otradnoe, P. tremula, 7.X.1995 Zmitrovich (LE 206311*). Primorie. Ternei Dist.: Sikhote-Alin Nat. Res., P. tremula, 20.VIII.2012 Malysheva (LE 303419*).

Globulisebacina fulva. Portugal. Castelo Branco: São Fiel, Eucalyptus globulus, XII.1903 Torrend 438 (S F20578, lectotype of Exidia fulva).

\section{Results}

While discussing generic names of the European heterobasidiomycetes, Donk (1966) preferred Craterocolla as the correct genus for T. cerasi and rejected two older genera, Ditangium and Poroidea, since they were based on anamorphic stages. His solution followed Art. 59 of the Montreal Code (1961) and was accepted by the subsequent authors. However, Art. F.8.1 of the current Code (2018) prescribes to choose the oldest legitimate name, whether teleomorphic or anamorphic, for naming a genus. Therefore, Ditangium should be used instead of Craterocolla if we assume that their type species, D. insigne P. Karst. and T. cerasi, are congeneric.

The protologue of T. cerasi (Schumacher 1803: 438) gives no clear answer what was the species it had been intended for. It referred to a jelly fungus with cerebriform, substipitate, reddish fructifications ('gyroso-lobata substipitata dilute purpurascens diaphana') occurring on bark and wood of cherry trees in Denmark. Donk (1966) argued that it most probably implies the 
imperfect stage of an ascomycete; he was apt to associate it with Sirobasidium cerasi Bourdot \& Galzin. If his opinion is accepted, then $T$. cerasi becomes an older name for $S$. cerasi and Craterocolla replaces Endostilbum Malençon (Ascomycota) at the generic level. We find these taxonomic changes disadvantageous and prefer to follow the prevailing understanding of T. cerasi as a heterobasidiomycete with a characteristic anamorphic stage (see also Recommendation 9A4 of the Code). To confirm this tradition, a neotype for T. cerasi is designated below.

Neuhoff (1935) considered T. cerasi (as Ditangium cerasi (Schumach.) Costantin \& L.M. Dufour) and D. insigne (the generic type of Ditangium) as taxonomic synonyms. On the other hand, Laurila (1939) and Eriksson (1958) continued to label North European collections as D. insigne. They argued that different distribution areas (temperate versus boreal Europe) and host preferences (Prunus cerasus versus Picea) supported the interpretation that two independent 'biological species' were present. In order to investigate this hypothesis, the authentic specimen of $D$. insigne (selected as a lectotype below), the holotype of Exidia testacea Raitv. (synonymized with $C$. cerasi by Malysheva 2012) and 19 specimens of $D$. cerasi s.l. collected from various host over temperate-boreal Eurasia have been studied by morphological and DNA methods.

Analyses of three datasets and their comparison with morphological (macroscopic and microscopic features of basidiocarps) and ecological (host preferences) features, as well as geographic patterns, give us the following results:

1. nrITS phylogeny. The final alignment contained 584 characters (including gaps). The overall topologies of the ML and BI trees were visually identical and divided ITS sequences in two groups (Fig. 1):

1) a large group ( $p p=0.92, b s=74)$ containing sequences from lectotype of $D$. insigne, holotype of E. testacea and 16 other specimens of which 14 are obtained for the present study. ITS sequences of two specimens found on $P$. cerasus in Czech Republic (X4196, 4197), one Norwegian specimen from Alnus incana (VS 11073) and two Caucasian collections from coniferous hosts (LE 254073, 254074) are identical while the rest of sequences (specimens from coniferous hosts and Betula spp., all but one from boreal or continental parts of Eurasia) show small differences (3-6 bp) from them. As said above, T. cerasi was described from temperate Europe (Denmark) as inhabiting bark and wood of P. cerasus. Consequently, we select one of the sequenced specimens found on cherry tree in temperate Europe (Czech Republic) as a neotype of T. cerasi (see below);

2) a small clade $(\mathrm{pp}=0.99$, bs $=86)$ containing sequences of two specimens found on Populus tremula (LE 206311 from North-West Russia and LE 303419 from Russian Far East) plus one collection from Alnus (LE 231836, Altai). Four bp difference exists between aspen- and alder-dwelling specimens. The variability of the ITS region in both clades prompted us to produce a tefl dataset.

2. tef1 phylogeny. The final alignment contained 612 characters (including gaps). All clades detected in tefl phylogeny are strongly supported and the overall picture is more nuanced (Fig. 2).

1) a large clade with $T$. cerasi neotype $(\mathrm{pp}=0.96, \mathrm{bs}=$ 87 ) is divided in three lineages:

- lineage A includes the neotype of T. cerasi and three collections from Caucasus; conidial stage is usually present and develops separately from the teleomorph, conidia are slightly or distinctly curved;

- lineage B includes two specimens from North Europe morphologically identical to the type of $D$. insigne; conidia are of the same shape as in the previous clade, slightly or distinctly curved but on average longer;

- lineage $\mathrm{C}$ includes five collections from the continental parts of Eurasia; conidial stage is rare and it develops directly on teleomorphic fructifications, conidia moderately or strongly curved and on average wider than in the two previous subclades;

2) a small clade ( $\mathrm{pp}=1, \mathrm{bs}=100)$ containing specimens from Alnus and Populus which have no crater-like anamorphic stage. This clade is represented by two lineages interpreted here as two different species:

- $\quad$ three aspen-dwelling specimens (LE 206311, LE 303419 plus VH 28811 from Finland) having identical tefl sequences are named Ditangium incarnatum (based on Dacrymyces incarnatus P. Karst., see below);

- the Alnus-dwelling specimen LE 231836 showing considerable difference $(4 \%)$ in tefl region versus D. incarnatum represents a new species, D. altaicum.

3. Combined nrITS + tefl phylogeny. The final alignment contained 1219 characters (including gaps). The two-gene combination was not effective enough to clarify the relationships within the group further. However, nrITS + tefl phylogeny clearly uncovers three lineages corresponding to the three morphological species-D. altaicum, D. incarnatum and D. cerasi (Fig. 3). The combined phylogeny does not support further splitting of the latter lineage, as opposed to morphological data and, partly, geographic distribution and host preferences. This problem should be addressed by using still other genetic markers. For the moment, we accept Neuhoff's opinion and treat $T$. cerasi and $D$. insigne as taxonomic synonyms. 
Fig. 1 Bayesian phylogram for the nrITS dataset. Collection numbers are given for all sequences. Support values (Bayesian posterior probability/ maximum likelihood bootstrap values) are given above the branches. Scale bar shows expected changes per site

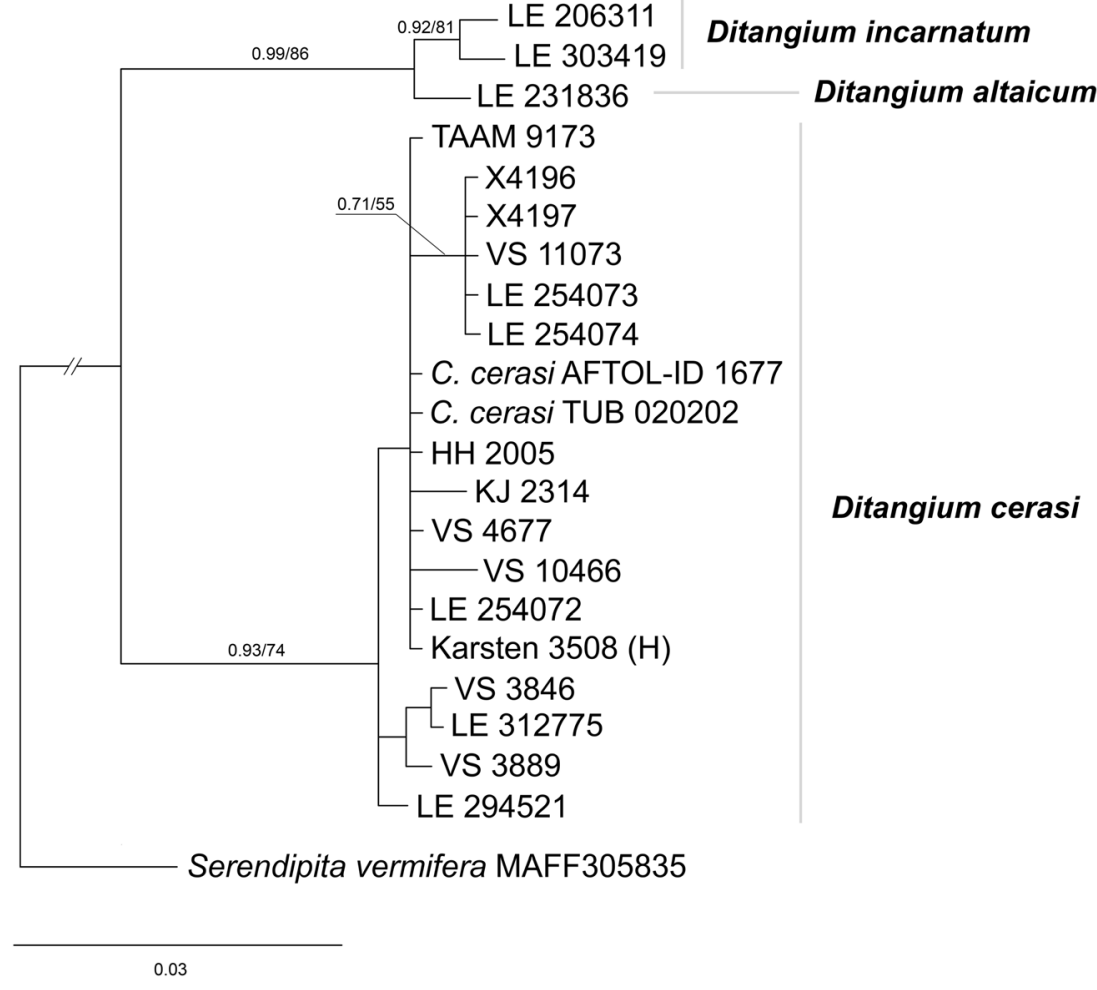

Fig. 2 Bayesian phylogram for the tefl dataset showing major lineages of Ditangium. Collection numbers are given for all sequences. Support values (Bayesian posterior probability/ maximum likelihood bootstrap values) are given above the branches. Scale bar shows expected changes per site

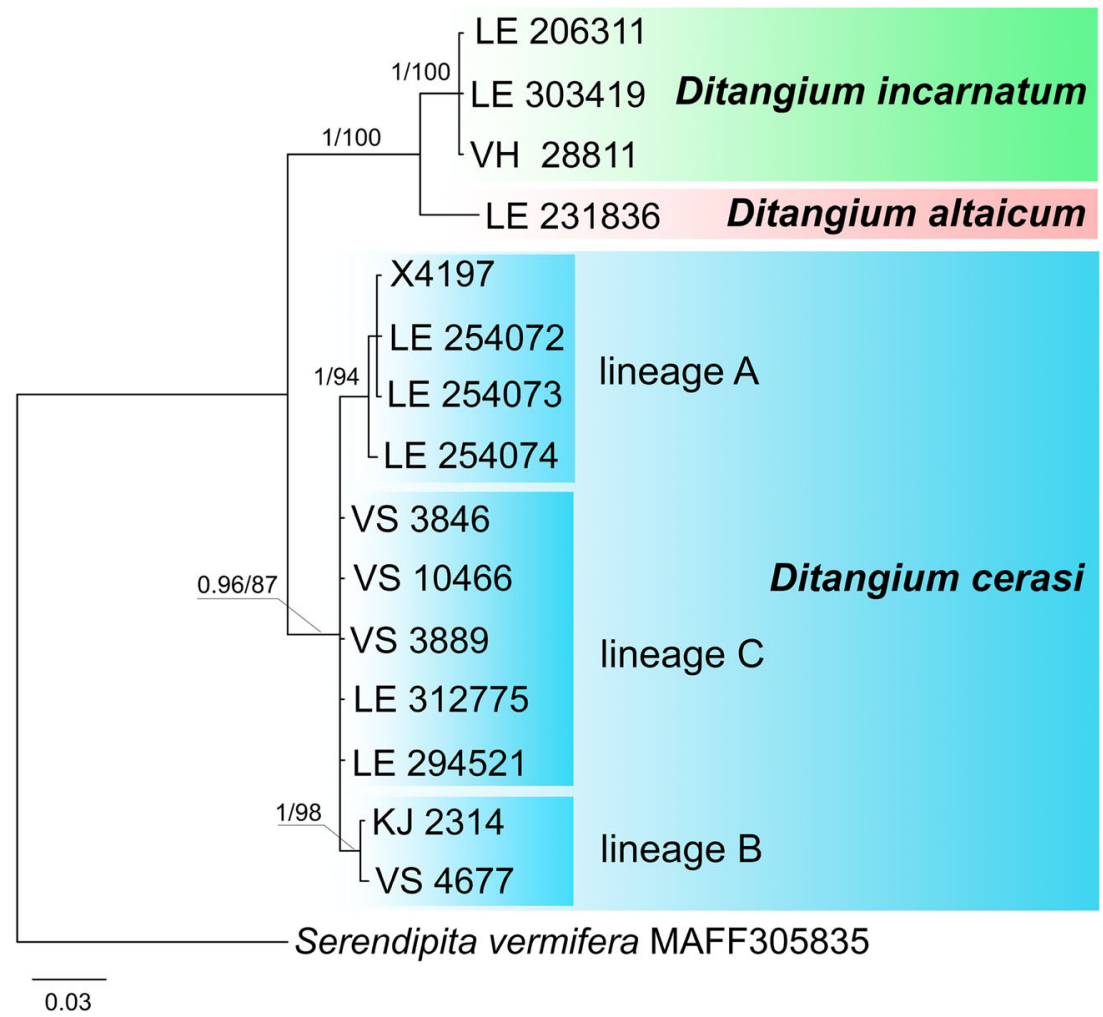


Fig. 3 Combined nrITS + tefl topology from ML analysis. Collection numbers are given for all sequences. Support values (maximum likelihood bootstrap values/Bayesian posterior probability) are given above the branches. Scale bar shows expected changes per site

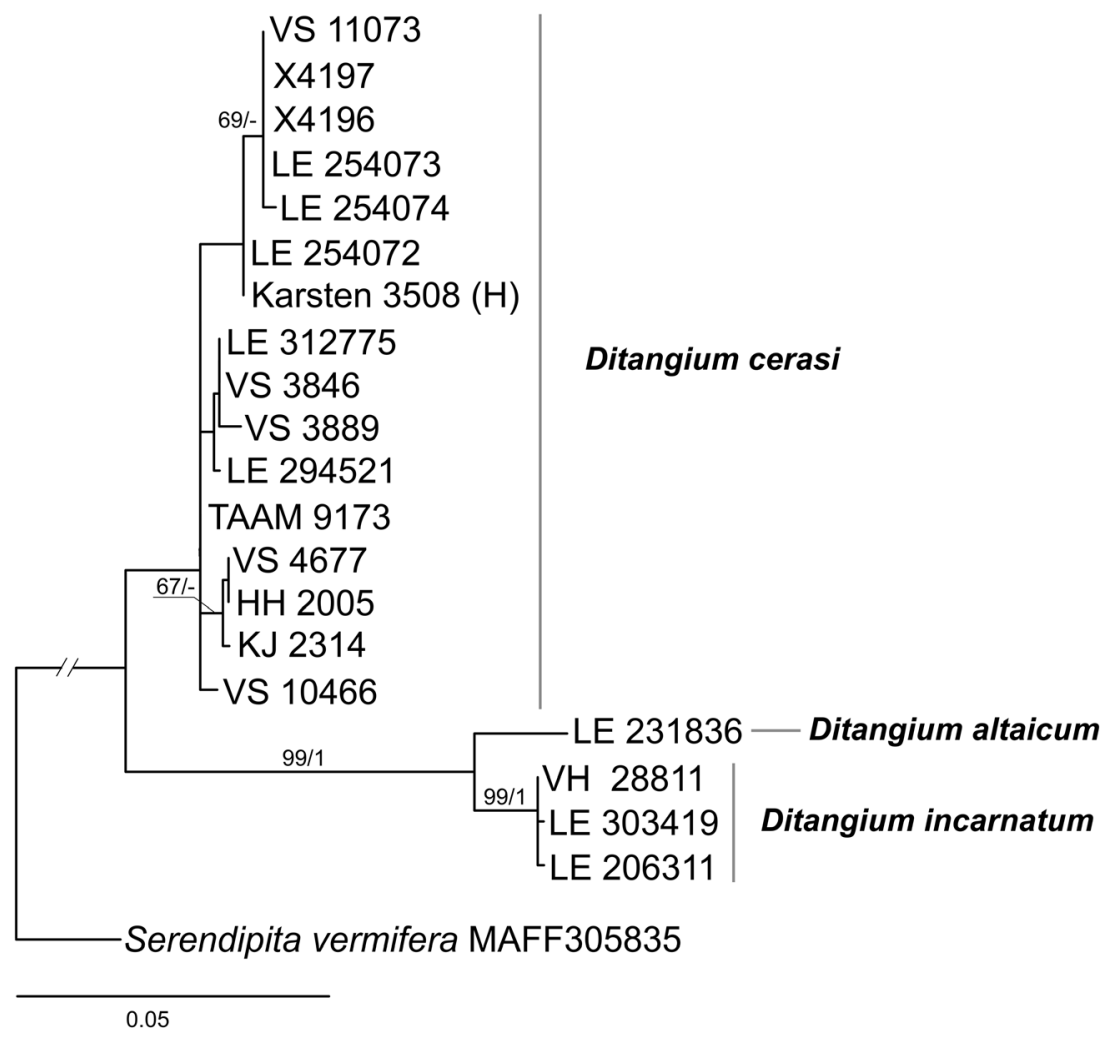

Holotype. Russia. Altai Republic: Ulagan Dist., Altai Nat. Res., Alnus sp., 18.VIII.2008 Malysheva (LE 231836).

MB 827990

Basidiocarps cerebriform, 3-7 mm in diam. and $1.5-3 \mathrm{~mm}$ thick, pink to brick-red. Conidial fructifications absent. Hyphae clampless, interwoven or ascending, abundantly encrusted by oily matter; tramal hyphae thin-walled, 1.5$2.5 \mu \mathrm{m}$ in diam., subhymenial hyphae thin-walled, $1-$ $2.5 \mu \mathrm{m}$ in diam. Hyphidia abundant, covering hymenial surface, richly branched, apical branches $1-1.2 \mu \mathrm{m}$ in diam. Basidia (2) 4-celled, obovate to subglobose, (8.0-) 8.1-9.9 $(-11.0) \times(6.7-) 6.8-7.8(-8.0) \mu \mathrm{m}(n=20 / 1)$, sterigmata up to $22 \times 1-1.5 \mu \mathrm{m}$. Basidiospores narrowly fusiform, straight or slightly concave, $(7.8-) 8.0-10.3(-11.8) \times(2.8-)$ $2.9-3.3(-3.6) \mu \mathrm{m}(n=30 / 1), L=9.11, W=3.11, Q^{\prime}=(2.3-)$ 2.6-3.4 (-3.6), $Q=2.93$.

Remarks: Ditangium altaicum possesses small-sized basidiocarps and no conidial stage and thus it is more or less macroscopically identical to $D$. incarnatum. These species can be separated mainly due to differently looking basidiosporesfusiform and almost always straight in D. altaicum and cylindrical and often clearly curved in D. incarnatum. Ditangium altaicum is so far known only from the locus classicus in Siberia.

Ditangium cerasi (Schumach.) Costantin \& L.M. Dufour, Nouvelle flore des champignons: 207, 1891. (Figs. 4b, 5 and 6a-c). 
Fig. 4 Basidiospores of Ditangium spp.: a D. altaicum (LE 231836, holotype), b

D. cerasi (VS 10466), c

D. incarnatum (LE 206311).

Scale bar- $10 \mu \mathrm{m}$
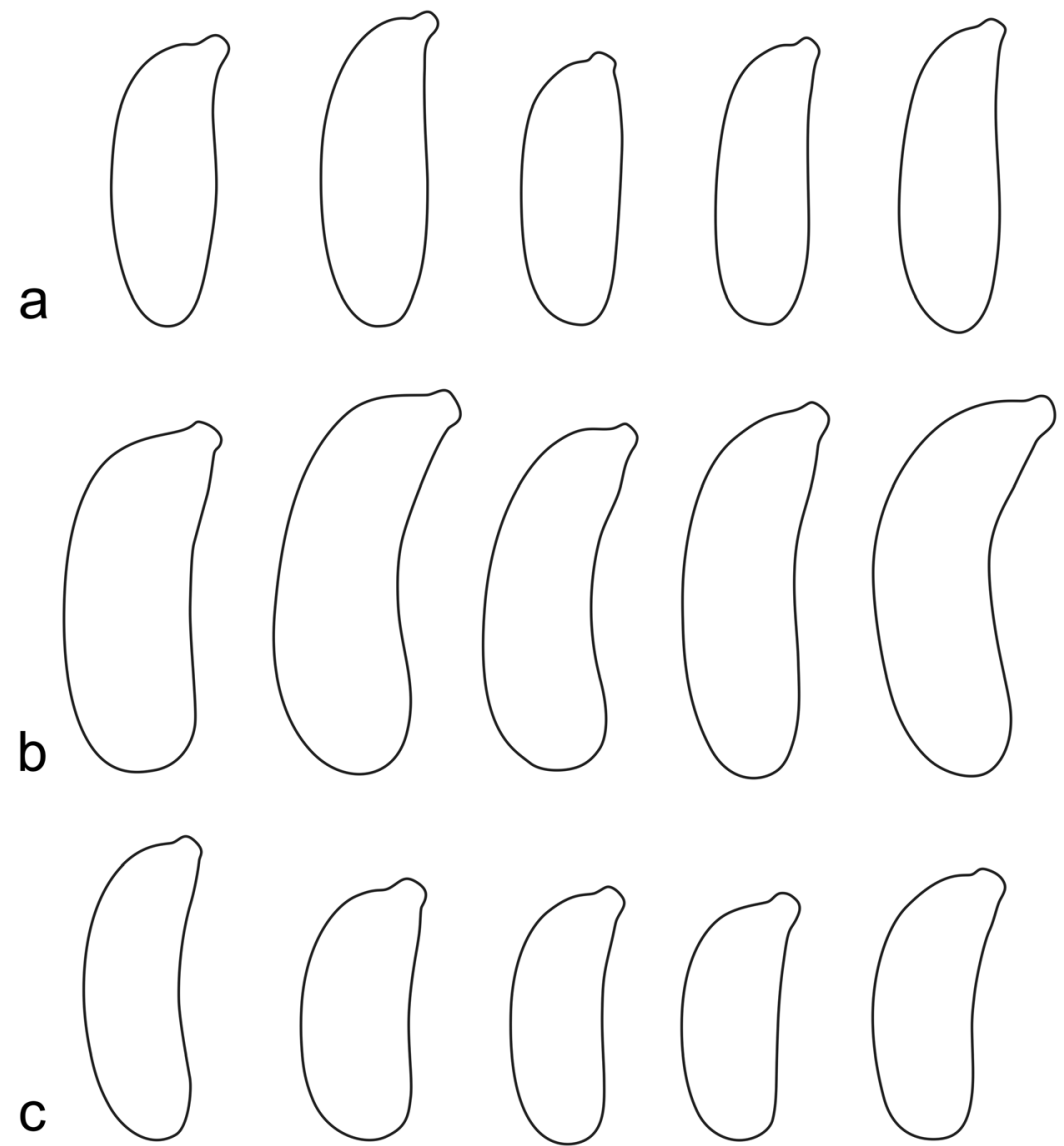

$=$ Ditangium insigne P. Karst., Fungi Fenniae Exsiccati 7:

$\equiv$ Tremella cerasi Schumach., Enumeratio Plantarum, in Partibus Saellandiae Septentrionalis et Orientalis Crescentium 2: 438, 1803. Neotype (selected here). Czech Republic. South Bohemia: Tábor, Chýnov, Prunus cerasus, 30.IX.2002 Kout (H 7008919, isoneotype-KBI) (MBT 383584).

$\equiv$ Craterocolla cerasi (Schumach.) Bref., Unters. Gesamtgeb. Mykol. 7: 99, 1888.

三 Exidia cerasi (Schumach.) Ricken, Vadem. Pilzfr.: 274, 1918.

Fig. 5 Microstructures of Ditangium spp.: (1) Ditangium cerasi (VS 10466): basidia and hyphidia; (2) D. cerasi (VS 10466): subhymenial hyphae; (3) conidia of $D$. cerasi (lineage A) (LE 254072); (4) conidia of D. cerasi (lineage B) (Karsten 3508); (5) conidia of D. cerasi (lineage C) (VS 3889); (6) conidiophores of D. cerasi (LE 254072 - left, VS 3889 - right).

Scale bar- $10 \mu \mathrm{m}$
<smiles>C=CC=CC=C</smiles>




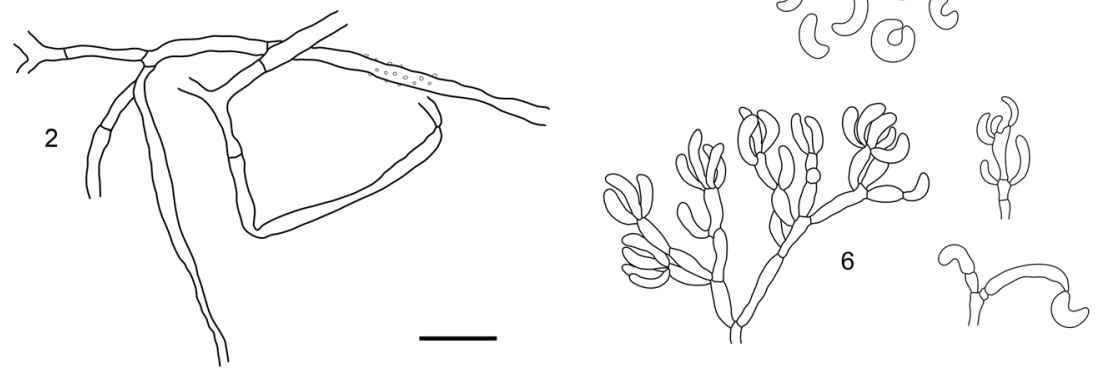
Fig. 6 Fructifications of Ditangium spp.: a D. cerasi (VS 3889, lineage C) (teleomorph and anamorph), b D. cerasi (LE 254073, lineage A) (old discoloured teleomorph), c D. cerasi (LE 254074, lineage A) (teleomorph and anamorph), $\mathbf{d}$ D. incarnatum (LE 303419). Scale bar $-5 \mathrm{~mm}$

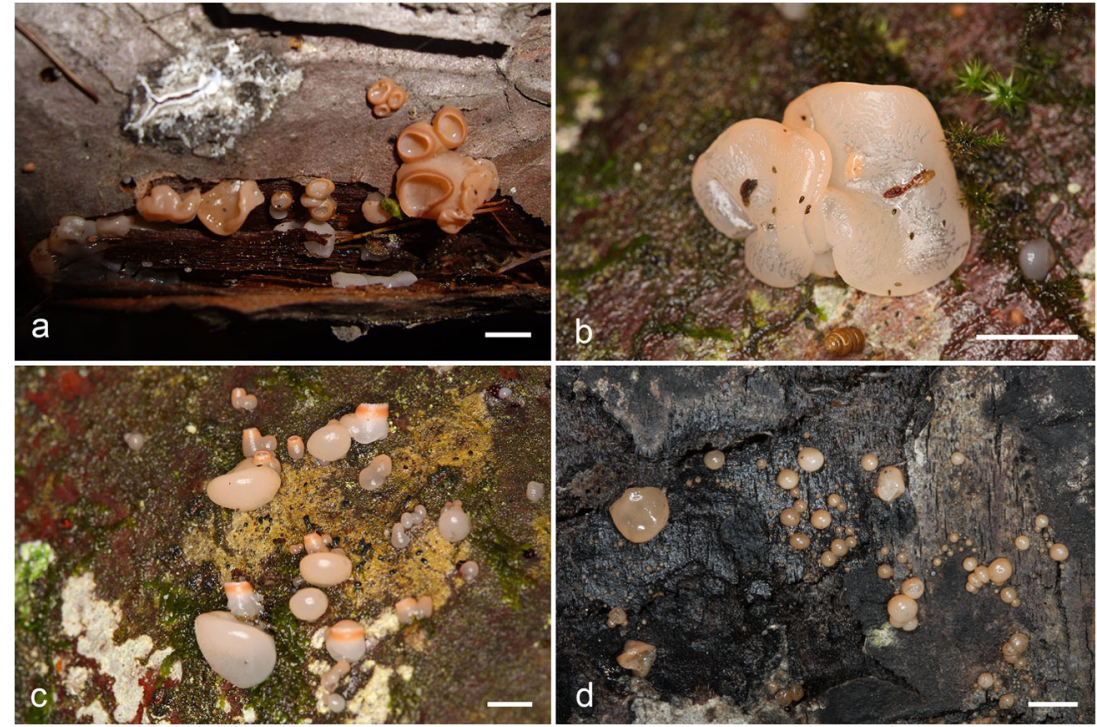

Mansky Dist., Badzhei, Abies sibirica, 6.IX.1958 Parmasto (TAAM 9173).

Basidiocarps cerebriform, 5-20 mm in diam., 3-8 $\mathrm{mm}$ thick, pink to brick-red, senescent basidiocarps sometimes fading to almost white. Conidial fructifications occasionally present, appearing on or together with teleomorphic basidiocarps, crater-like, 1-2 mm in diam. Hyphae clampless, interwoven or ascending, abundantly encrusted by oily matter; tramal hyphae thin- to slightly thick-walled, (1.5-) 2-4 $\mu \mathrm{m}$ in diam., occasionally inflated up to $5 \mu \mathrm{m}$ in diam., subhymenial hyphae thin-walled, (1-) 1.5-3 $\mu \mathrm{m}$ in diam. Hyphidia abundant, covering hymenial surface, sparsely or richly branched, apical branches 1-2 $\mu \mathrm{m}$ in diam. Basidia (2) 4-celled, obovate to subglobose, (7.8-) 8.1-11.2 (-12.8) × (6.1-) 6.6-9.6 (10.0) $\mu \mathrm{m}(n=65 / 8)$, sterigmata up to $30 \times 1-2 \mu \mathrm{m}$. Basidiospores narrowly cylindrical to cylindrical, slightly to distinctly curved, (7.1-) 7.2-12.9 (-15.2) × (2.6-) 2.7-4.4 (4.5) $\mu \mathrm{m}(n=320 / 13), L=8.32-10.72, W=2.98-3.95$, $Q^{\prime}=(2.0-)$ 2.1-3.9 (-4.1), $Q=2.44-3.34$. Hyphae of anamorphic fructifications similar to those of a teleomorph but often with thickened walls (except thin-walled conidiiferous branches); conidia thin-walled, cylindrical, predominantly slightly to moderately curved (lunate), (4.8-) 4.9-8.2 ($9.2) \times(1.7-) 1.8-2.3(-2.6) \mu \mathrm{m}(n=60 / 3), L=5.63-6.91$, $W=1.97-2.20, Q=2.87-3.27$ (lineage A-Fig. 5.3) or (5.2-) 5.8-8.8 (-9.4) ×(1.6-) 1.8-2.5 (-2.8) $\mu \mathrm{m}(n=49 / 3), L=$ $7.06-7.67, W=1.98-2.27, Q=3.38-3.58$ (lineage BFig. 5.4), or moderately to strongly curved, (5.7-) 5.8-8.9 $(-9.1) \times(2.1-) 2.2-3.0(-3.1) \mu \mathrm{m}(n=20 / 1), L=6.88, W=$ 2.62, $Q=2.66$ (lineage C-Fig. 5.5).

Remarks: As understood here, D. cerasi is a widespread species in Eurasia although it is rarely collected. It occurs on various hosts-both conifers (Abies, Picea,
Pinus) and deciduous trees (Alnus, Betula, Malus, Prunus, Quercus).

Ditangium incarnatum (P. Karst.) Spirin \& V. Malysheva, comb. nov. (Figs. 4c and 6d).

$\equiv$ Dacrymyces incarnatus P. Karst., Medd. Soc. Fauna Fl. Fennica 14: 83, 1887. Lectotype (selected here). Finland. Etelä-Häme: Tammela, Mustiala, Salix pentandra, 1.IX.1886 Karsten 1324 (H 6049583) (MBT 383580).

MB 827991

Basidiocarps normally pustulate, $1-1.5 \mathrm{~mm}$ in widest dimension, rarely fusing together and then cerebriform, up to 5$6 \mathrm{~mm}$ in diam. and 3-4 mm thick, pink to yellowish-cream. Conidial fructifications absent. Hyphae clampless, interwoven or ascending, abundantly encrusted by oily matter; tramal hyphae thin- to slightly thick-walled, (2-) 2.5-3.5 $\mu \mathrm{m}$ in diam., subhymenial hyphae thin-walled, 1-2.5 $\mu \mathrm{m}$ in diam. Hyphidia abundant, covering hymenial surface, richly branched, apical branches 0.8-1.2 $\mu \mathrm{m}$ in diam. Basidia (2) 4-celled, obovate to subglobose, (7.1-) 7.2-10.6 ($11.0) \times(6.1-) 6.2-8.0(-8.1) \mu \mathrm{m}(n=30 / 3)$, sterigmata up to $34 \times 1-1.5 \mu \mathrm{m}$. Basidiospores narrowly cylindrical, slightly to distinctly curved, (6.0-) 6.3-10.2 (-10.3) × (2.6-) 2.7-3.6 (3.7) $\mu \mathrm{m}(n=80 / 4), L=7.10-8.72, W=2.94-3.09, Q^{\prime}=(2.1-)$ 2.2-3.3 (-3.5), $Q=2.42-2.87$.

Remarks: This species was described by Karsten (1887) based on a single collection from Finland but it has remained unknown or unrecognised (cf. McNabb 1973). Morphological study revealed that Karsten's type is identical to four other specimens collected on wood of Salicaceae in temperatehemiboreal Eurasia. Ditangium incarnatum differs from D. cerasi in having essentially smaller basidiocarps and on average shorter basidiospores. No conidial stage associated 
with $D$. incarnatum has been detected. The closely related D. altaicum has differently shaped (fusiform) basidiospores.

Globulisebacina fulva (Bres. \& Torrend) Spirin, comb. nov.

E Exidia fulva Bres. \& Torrend, Brotéria, Sér. Bot. 11: 89, 1913. Lectotype (selected here). Portugal. Castelo Branco: São Fiel, Eucalyptus globulus, XII.1903 Torrend 438 (S F20578) (MBT 383582).

\section{MB 827992}

Basidiocarps pustulate or cupulate, gregarious, gelatinous, yellowish to brownish, $1-1.5 \mathrm{~mm}$ in diam., $0.1-0.3 \mathrm{~mm}$ thick, partly fusing but remaining discernable. Hyphal structure monomitic. Hyphae ascending, hyaline to brownish, richly branched, some twisted, simple-septate, (2.0-) 2.2-3.3 (3.7) $\mu \mathrm{m}$ in diam. $(n=20 / 1), \mathrm{CB}(+)$, some hyphae bearing amorphous brownish incrustation (seen in Cotton Blue). Cystidia absent; hyphidia abundant, covering hymenial surface, hyaline to brownish, richly branched, 1.5-2.5 $\mu \mathrm{m}$ in diam. at the apical part. Basidia broadly ellipsoid to ovoid, hyaline to pale brownish, 2-4-celled, with longitudinally or obliquely oriented inner septa, $11.5-16 \times 9-11.5 \mu \mathrm{m}(n=12$ / 1), without a basal clamp, some senecent basidia slightly thick-walled; sterigmata subulate, up to $15 \times 2.5-4 \mu \mathrm{m}$. Basidiospores cylindrical, more or less clearly curved, hyaline, thin-walled, (11.3-) 12.0-15.8 (-18.2) × (4.5-) 4.8-7.7 $(-7.8) \mu \mathrm{m}(n=20 / 1), L=14.07, W=6.20, Q^{\prime}=(1.8-) 2.0-$ $2.6(-2.8), Q=2.30$.

Remarks: Searching for older names potentially connected to Ditangium spp. led us to Exidia fulva, a completely forgotten species described from Portugal. Yellowish or brownish basidiocarps and encrusted, clampless hyphae of the lectotype are reminiscent of Ditangium although basidia and basidiospores of E. fulva are essentially larger. In our opinion, E. fulva is very similar to or probably identical with Exidia rolleyi L.S. Olive as the latter has been introduced by Olive (1958), Wells (1975) and Roberts (2011). The latter species was placed in Efibulobasidium K. Wells (Wells 1975) and recently moved to its own genus, Globulisebacina Oberw. et al. (2014) (Sebacinales, Basidiomycota). Therefore, a new combination in Globulisebacina is proposed.

Acknowledgments The curators of herbaria TAAM, UPS, CWU, S, TRH are thanked for providing specimens for loan.

Funding information Open access funding provided by University of Helsinki including Helsinki University Central Hospital. The research was supported by Norwegian Biodiversity Information Centre (the project 'A survey of Norwegian jelly fungi', grant number knr. 44-15) (the authors KHL and VS), by Komarov Botanical Institute, Russian Academy of Sciences (project AAAA-A19119020890079-6) (the author VM), by the Estonian Science Agency (project IUT20-30) and the European Union through the
European Regional Development Fund (Centre of Excellence FIBIR) (the author AS).

Open Access This article is distributed under the terms of the Creative Commons Attribution 4.0 International License (http:// creativecommons.org/licenses/by/4.0/), which permits unrestricted use, distribution, and reproduction in any medium, provided you give appropriate credit to the original author(s) and the source, provide a link to the Creative Commons license, and indicate if changes were made.

\section{References}

Brefeld O (1888) Basidiomyceten II. Protobasidiomyceten. Unters Ges Mykol 7:1-178

Deshmukh S, Huckelhoven R, Schafer P, Imani J, Sharma M, Weiss M, Waller F, Kogel KH (2006) The root endophytic fungus Piriformospora indica requires host cell death for proliferation during mutualistic symbiosis with barley. Proc Natl Acad Sci U S A 103(49):18450-18457

Donk MA (1966) Check list of European hymenomycetous Heterobasidiae. Persoonia 4:145-335

Eriksson J (1958) Studies in the Heterobasidiomycetes and Homobasidiomycetes - Aphyllophorales of Muddus National Park in North Sweden. Symb Bot Upsalienses 16:1-172

Fries EM (1822) Systema mycologicum. Vol. 2. Lund

Gardes M, Bruns TD (1993) ITS primers with enhanced specificity for basidiomycetes - application to the identification of mycorrhizae and rusts. Mol Ecol 2:113-118

Hansen L, Knudsen H (eds) (1997) Nordic Macromycetes. 3. Nordsvamp, Copenhagen

Karsten PA (1867) Fungi Fenniae Exsiccati. Vol. 7. Abo

Karsten PA (1887) Symbolae ad mycologiam Fennicam. Medd Soc Fauna Flora Fennica 14:78-84

Laurila M (1939) Basidiomycetes novi rarioresque in Fennia collecti. Ann Bot Soc Zool Bot Vanamo 10:1-24

Malysheva V (2012) A revision of the genus Exidia (Auriculariales, Basidiomycota) in Russia. Mikol Fitopat 46:365-376

McNabb RFR (1973) Taxonomic studies in the Dacrymycetaceae. VIII. Dacrymyces Nees ex Fries. New Zealand J Bot 11:461-524

Miettinen O, Vlasák J, Rivoire B, Spirin V (2018) Postia caesia complex (Polyporales, Basidiomycota) in temperate Northern Hemisphere. Fung Syst Evol 1:101-129

Neuhoff W (1935) Die Gallertpilze (Tremellineae). Die Pilze Mitteleuropas 2(1):1-8

Neuhoff W (1936) Die Gallertpilze Schwedens. Ark. Bot. 28A:1-57

Oberwinkler F, Riess K, Bauer R, Garnica S (2014) Morphology and molecules: the Sebacinales, a case study. Mycol Progress 13:445470

Olive LS (1958) The lower Basidiomycetes of Tahiti (continued). Bull Torrey Bot Club 85:89-110

Pilát A (1957) Übersicht der europäischen Auriculariales und Tremellales unter besonderer Berücksichtigung der tschechoslowakishen Arten. Acta Mus Nat Prag 13B:115-210

Rambaut A, Suchard MA, Xie D, Drummond AJ (2014) Tracer v1.6. http://tree.bio.ed.ac.uk/software/tracer/ (accessed on 20.12.2017)

Rehner SA, Buckley E (2005) A Beauveria phylogeny inferred from nuclear ITS and EF1-a sequences: evidence for cryptic diversification and links to Cordyceps teleomorphs. Mycologia 97:84-98

Roberts P (2011) Marchandiobasidium aurantiacum and Efibulobasidium rolleyi: two unusual fungi on a Welsh apple twig. Field Mycol 12:132-134

Ronquist F, Teslenko M, Mark P, Ayres DL, Darling A, Höhna S, Larget B, Liu L, Suchard MA, Huelsenbeck JP (2012) MrBayes 3.2: efficient Bayesian phylogenetic inference and model choice across a large model space. Syst Biol 61(3):539-542 
Saccardo PA (1888) Sylloge Hymenomycetum. Vol. II. Sylloge Fung 6: $1-928$

Sauter A (1880) Nachträge und Berichtungen zur Flora Herzogtums Salzburg. Mitth Ges Salzburger Landesk 20:213-219

Schumacher HCF (1803) Enumeratio plantarum, in partibus Sællandiae Septentrionalis et Orientalis crescentium. Vol. 2. Copenhagen

Tamura K, Stecher G, Peterson D, Filipski A, Kumar S (2013) MEGA6: molecular evolutionary genetics analysis version 6.0. Mol Biol Evol 30:2725-2729. https://doi.org/10.1093/molbev/mst197

Thiers B (2016) Index Herbariorum: a global directory of public herbaria and associated stuff [continuosly updated]. New York Botanical Garden's Virtual Herbarium. http://sweetgum.nybg.org/ih

Tulasne LR, Tulasne C (1873) New notes upon the Tremellinous fungi and their analogues. J Linnean Soc 13:31-42
Weiss M, Selosse MA, Rexer KH, Urban A, Oberwinkler F (2004) Sebacinales: a hitherto overlooked cosm of heterobasidiomycetes with a broad mycorrhizal potential. Mycol Res 108:1003-1010

Wells K (1975) Studies of some Tremellaceae. V. A new genus, Efibulobasidium. Mycologia 67:147-156

White TJ, Bruns T, Lee S, Taylor JW (1990) Amplification and direct sequencing of fungal ribosomal RNA genes for phylogenetics. In: Innis MA, Gelfand DH, Sninsky JJ, White TJ (eds) PCR protocols: a guide to methods and applications. Academic Press, New York, pp 315-322

Wojewoda W (1981) Mała flora grzybów. Tom 2. Krakow

Publisher's note Springer Nature remains neutral with regard to jurisdictional claims in published maps and institutional affiliations. 